\title{
Glycemic control and antimicrobial prophylaxis audit in cardiac surgery in Uruguay
}

\author{
H Albornoz*, G Saona, I Wall, A Perna \\ From International Conference on Prevention \& Infection Control (ICPIC 2011) \\ Geneva, Switzerland. 29 June - 2 July 2011
}

\section{Introduction / objectives}

Glycemic control in cardiac surgery patients (pts) is one important factor that affect the risk of surgical site infection and mortality. Antimicrobial (ATM) profilaxis is complex process in this pts.

We evaluated the antimicrobial prophylaxis and glycemic control en ptes operate of cardiac surgery (CS) in Uruguay.

\section{Methods}

An observational retrospective study of a population of cardiac surgery ptes operate between August 2006 and February 2007. A non proportional sample stratified by cardiac surgery center was selected and clinical records reviewed. Intra-operative and all values of the first 24 hours of plasmatic or percutaneous glucose concentration and data of antimicrobial prophylaxis (timing, ATMs, dose, intra-operative re-injection and duration) were recorded. Average peri-operative glycemia was estimated by area under the curve of glucose concentrationtime.

\section{Results}

610 (64.2 years, male $70.2 \%$, bypass surgery $74 \%$, diabetics 20.6\%) patients were operated in the 5 centers of CS in Uruguay, the sample included 180 pts. All pts had at least one perioperative glycemic value. Average perioperative glycemia concentration was $1.77 \mathrm{~g} / \mathrm{L}$ (diabetics 2.06, non diabetics $1.7 \mathrm{~g} / \mathrm{L}$ ). Ptes with postoperative infection had higher perioperative glycemia (all sites 1.89 vs $1.68 \mathrm{~g} / \mathrm{L}$, surgical site infections 1.9 vs $1.75 \mathrm{~g} / \mathrm{L}$, $\mathrm{p} Ð 0.001$ and $\mathrm{p}=0.049$, respectively). $43 \%$ of ptes received crystalline insulin infusion. $96.4 \%$ received one dose of ATM before the incision, $75.2 \%$ in the hour previous. $31.7 \%$ received intraoperative reinyection.

Fondo Nacional de Recursos. Uruguay, Montevideo, Uruguay

\section{Conclusion}

Glycemic control and ATM prophylaxis need to be improved in Uruguay.

\section{Disclosure of interest \\ None declared.}

Published: 29 June 2011

doi:10.1186/1753-6561-5-S6-057

Cite this article as: Albornoz et al:: Glycemic control and antimicrobial

prophylaxis audit in cardiac surgery in Uruguay. BMC Proceedings 20115 (Suppl 6):057.
Submit your next manuscript to BioMed Central and take full advantage of:

- Convenient online submission

- Thorough peer review

- No space constraints or color figure charges

- Immediate publication on acceptance

- Inclusion in PubMed, CAS, Scopus and Google Scholar

- Research which is freely available for redistribution
() Biomed Central

\section{() Biomed Central}

